\title{
Determinants of Migrations and Remittances: Evidence from Rural Sector of Sri Lanka
}

\author{
R. A. P. I. S. Dharmadasa \\ Uva Wellassa University of Sri Lanka \\ K. K. H. M. Rathnayake \\ Uva Wellassa University of Sri Lanka
}

\begin{abstract}
Agriculture remains as one of the major sources of employment to the rural community in Sri Lanka. However, problems such as inadequate land and capital, low productivity and personal attitudes have pushed the rural agricultural worker to migrate out of the sector. As the decision to migrate is made at the household level, characteristics of the household shape up the decision to migrate and send remittances to the origin communities. Therefore, this study is an attempt to find the determinants of migration and the remittances of the rural sector of Sri Lanka with special emphasis on household level characteristics. In identifying the determinants, the study has estimated several multinomial logit models separately based on the status of migration and receipt of remittances using a nationally representative data set of Household Income and Expenditure Survey (2009/2010). The results reveal that human capital characteristics are not major positive determinants of rural sector migration and receiving remittances implying that households with better education remain in the rural sector. Rural households with more members tend to have more migrants while it is a negative determinant of the receipt of remittances.
\end{abstract}

Corresponding Author:

Ms. K. K. M. H. Rathnayake is a Temporary Lecturer at the Department of Export Agriculture, Uva Wellassa University of Sri Lanka. E-mail: kkhmr222rathnayake@gmail.com 
Results also suggest that rural households receive more remittances from internal migrants when they have school age children. Based on these results, this study concludes that people diversify into different income earning strategies such as migration when they have more household members while education has contributed positively to keep the rural households in the sector. Therefore, the retaining human capital can be used in the rural development process if proper policies are implemented.

\section{Keywords}

Determinants, Migration, Remittances, Rural Sector

\section{Introduction}

Change of residence from one administrative area to another within the same country is known as internal migration while the change of residence from the recognized borders of one country is known as international migration (Department of Census and Statistics, 2015). In Sri Lankan population 16.9 per cent of the is a lifetime migrant within the country while the highest percentage of lifetime migrants are found within Colombo district followed by Gampaha (Department of Census and Statistics, 2015). The lowest is recorded in districts of Baticaloa. The dominant age group in migration varies between 25-39 years whereas many female migrants belong to the age group below 25 years (Department of Census and Statistics, 2015). It is also interesting to note that about 20.2 per cent of the population in Sri Lanka has changed the district of residence at least once.

The main purpose of migration is to find better paying employment opportunities and working conditions (Jayawardhana \& Jaythilaka, 2009) as well as economic considerations (Eelens \& Schampers, 1990). The World Bank (2007) identifies the diversification of the income portfolio to be one of the major reasons for internal migration. Other main reasons are backed by the notion of internal migration being a strategy for survival and poverty reduction as well as a means to accumulate assets (Jayawardhana and Jaythilaka, 2009). Overall much of internal migration occurs due to economic reasons prevailing sending regions (Perera, 2005; International Organization for Migration [IOM], 2005; Eelens \& Schampers, 1990; Department of Census and Statistics, 2015). Among the very reasons, seeking employment opportunities (Perera, 2005), income disparity among 
regions (World Bank, 2007) can also be considered as major determinants of internal migration. Moreover, the Department of Census and Statistics (2015) shows that the marriage is the most prominent factor for internal migration. Perera (2005) reveals that improved levels of income earnings, improved working conditions and housing, better services and opportunities for labor participation are a consequence of internal migration. However, World Bank (2007) indicates that opportunities through internal migration are limited. According to the same report by the World Bank (2007), internal migration in Sri Lanka has doubled between the periods of 1996/1997 and 2003/2004 due to the widened economic attributes between rural areas and the rest of the country.

The Middle Eastern (ME) region dominates the foreign employment market of Sri Lanka, accounting for more than 90 percent of departures from the country (Central Bank of Sri Lanka [CBSL], 2016) with the majority being unskilled workers and housemaids. Although the wages of unskilled workers and housemaids are low in comparison to the wages earned by high skilled and professional migrant workers, the earnings abroad remain quite high. This is often several times the amount a worker can earn back at home. Furthermore, casual workers employed back at home do not usually have regular work due to seasonality, changing weather conditions, etc. and as a result, people tend to work abroad for a higher and regular wage despite it being restricted to a fixed period. This explains why there is a constant supply of labour from poorer countries such as Sri Lanka to the ME region. According to the Sri Lanka Bureau for Foreign Employment (2016), the main administrative body regulating migration, more than one million Sri Lankans are employed abroad, with an outflow of approximately 263,443 persons in 2015. Within the ME region Saudi Arabia, Qatar, United Arab Emirates and Kuwait accounted for 84.34 per cent of total departures for foreign employment in 2015 (CBSL, 2016). Greater part of the remittances in 2015 (54 per cent) originates from the ME housemaids and the unskilled workers (57.4 per cent of total migrants).

According to the economic and social statistics of CBSL (2016), migration to ME has reduced from 277,994 in 2014 to 240,659 in 2015. Out of 92.6 per cent of international migrants are in the age group between 18 59 years among which 72 per cent are from the rural sector. Male 
population that is abroad for reasons of employment accounts for 54.2 percent and are temporary residents of Saudi Arabia, Qatar and Emirates; while 66 per cent of the female population who temporary reside abroad are found to be residents of Kuwait, Saudi Arabia, and Emirates (Department of Census and Statistics, 2015).

The decision to participate in off-farm activities such as migration is primarily made at the household level (Taylor, Rozelle, \& Brauw, 2003). However, it is surprising that studies on labour migration issues in the rural sector, especially focusing on the household characteristics that affect migration and decisions on remittance have not been adequately carried out in Sri Lanka. Shaw (2008) and Ukwatta (2010) disclose that most of the studies related to migration have been carried out to find out the pattern and social consequences of migration. Ranathunga (2011) also highlights this fact stating that the lack of data and statistics, has resulted in a dearth of studies related to migration. All this information implies the huge gap that exists within Sri Lankan literature with respect to migration and remittance.

Nearly 80 per cent of the Sri Lankan population belongs to the rural sector in which nearly 83 per cent of the total poor also happen to live in. The source of income for these households is predominantly dependent on agriculture (Department of Census and Statistics, 2011); and thus the remittances received through migration becomes very useful in diversifying the income portfolio. This study investigates household characteristics that are assumed to affect members of the household when making the decision to migrate and remit. For example, the number of dependents, the household size etc. can be important factors affecting the decision of migration within rural households of Sri Lanka (Dharmadasa \& De Zoysa, 2012). Therefore, a study highlighting the importance of determinants of migration and remittances will not only add to the existing literature by providing important implications on what household level characteristics influence the migration and decision remitting, but it would also be an eye opener to the nature of policies that should be implemented targeting the rural sector. This further contributes to the existing literature as well, since the study employs a relatively recent data set although the data set used in the study was not designed specifically to capture the effect of migration and remittances. The few studies that have analyzed the determinants of migration and 
remittances in Sri Lanka, have been carried out focusing on the estate sector in Sri Lanka (Dharmadasa \& De Zoysa, 2012; Dharmadasa, 2016). Therefore, this current analysis would provide a more contemporary insight on understanding the rural sector decision making process on migration and remittances.

\section{Literature Review}

The major determinant of migration proposed in Neo-Classical Theory is the wage differential between the sending region and the receiving region of migrants. The basis of the Todaro (1969), and Harris and Todaro (1970) models is also the wage differentials although their major focus is on the expected earnings. More recent findings by Nonthakot and Villano (2008) reveal that the disparity of wages between the farm and non-farm sectors generate farm labor out migration from lower wage rate areas. Apart from wage differentials, Cai and Wang (2003) investigate the spatial patterns and determinants of large scale migration in China and according to their findings, the differences in the expected income and the extent of marketization between regions are two important factors when determining the migration flows. Taylor et al. (2003) in their study on rural urban migration in China show that the rapid creation of off-farm enterprises resulting from the expansion of the economy, has led to an increase in the labor migration out of agriculture. Housen, Hopkins and Earnest (2013) highlight the reason for limited international migration from many low income countries. They reveal that the lack of human capital, especially high skilled labor or qualified professionals, as the major cause for such limited migration.

Sjaastad (1962) concentrates on human capital variables such as age and education. The Human Capital theory of Sjaastad (1962) reveals that age is a major determinant of migration and shows that migration decreases with age. According to Larson and Mundlak (1997), migration rates are higher in countries with a younger population. Migration literature also notes that the education levels of migrants and other household members positively influence the decisions regarding migration. This is highlighted by Sjaastad (1962), Adams (1989), Larson and Mundlak (1997), Mora and Taylor (2006), and Matsumoto, Kijima and Yamano, (2006). Almost all these authors stress that the propensity to migrate increases with higher education 
levels. Emphasis on the link between schooling and migration, Matsumoto et al. (2006) further shows how local language abilities (measured by the number of local languages one can speak) increase the propensity to migrate and participate in non-farm activities.

Mincer (1978) and Stark (1991) find the household size to be one of the major determinants in migration, and that it increases with the increase of the size of family in the source country. Mendola (2008) on the other hand shows that the number of working family members increases the benefits of migration, as family members working in different labor markets provide insurance for the members left behind regarding the available opportunities. Mendola (2008) further explains that the size of the household and the type of residence are positively associated with the migration decision. New Economics of Labor Migration also considers the household as a major determinant of migration and perceives migration as a risk sharing behavior of households.

Lee (1966) explains two types of factors affecting migration. They are the push factors and the pull factors. The push factors of migration are poverty, low income, small land holdings, lack of jobs and low wages; whereas the pull factors are the higher wages for highly skilled laborers and the strong network at the potential destination (World Bank, 2007). In a study carried out in Bangladesh, Ullah (2004) reveals that both push and pull factors affect migration decisions and they mention those factors as the search for work, landlessness, extreme poverty, loss of income, easy access to informal sectors in cities and joining families or relatives.

The number of poor people in a country or a region and the average quality of life also depends on how equally or unequally income is distributed (Soubbotina, 2004). The distribution of income can always be changed by migration due to the remittance effect while the inequality within sending areas and receiving areas could promote migration (Deshingkar, 2006). Uneven development and interregional inequalities may also lead to driving people from one region to another (World Bank, 2007; Deshingkar, 2006). It is also interesting to note that the income inequality related to caste, tribe, gender, and ethnicity is important in shaping migration (Deshingkar, 2006; Dharmadasa \& de Zoysa, 2012). Distance 
from origin to destination, which reflects the accessibility to transport networks, cost and risk of participation in migration and the accessibility to information and markets (Greenwood, 1970; Zhu \& Luo, 2010) also play a significant role in the migration decision.

Among the household characteristics, the educational level of the household heads (Lewin, Fisher, \& Weber, 2012) and experience in a particular type of work significantly influence the migration decision; while household ownership is also found to be a major determinant. Root and De Jong (1991) find that in the Philippines, higher educational level among adult members with few real estates is related to migration of some family members. In contrast, Dharmadasa and de Zoysa (2012) portray how the house ownership in tea estates of the Badulla district of Sri Lanka does not influence the decision to have a migrant member in a family. They further show that experience of the household head in tea estate work has negative association with having a migrant in a family. Another key finding of Mincer's migration studies (1978) states that there is an effect of the wife's wage rate and educational level on the propensity to migrate. Shields and Shields (1993) have also found that a wife's educational level has a strong positive impact on the migration. They further notice that the higher the wife's wage rate, the lower the family's migration propensity is. Lewin et al. (2012) indicate that the probability of migration is negatively associated with the age of the household head and the head being a female. A number of dependents defined as household members who are not currently employed (Zhu \& Luo, 2010) have a strong linkage with the migration decision as they are the people who stay at home protecting their properties (Zhao, 1999). However, certain other studies (Zhu \& Luo, 2006; Dharmadasa \& de Zoysa, 2012; Lewin et al., 2012) show that the propensity to have a migrant in families reduce with an increase in the number of dependents, due to the fact that the dependents have to be cared for.

It is not surprising that migration is determined by economic as well as non-economic factors at both the household and individual level. Zhao (1999) states that the decision to migrate by Chinese people, is affected by non-economic forces and they generally choose rural non-farm work over migration although migration offers large monetary returns. His findings are contradictory to the general view, which proposes that the more educated 
prefer non-farm work over migration, although in many cases better educated people positively select migration. In this study, the author further explains that the major impediment to migrate is the lack of safety during transportation and in destination cities as well as forced separation from families.

Migration is a viable economic decision made by the citizens in a country to lessen their income related risks while the remittances from migrants serve as insurance for households in the country of origin (Lucas \& Stark, 1985). International migration has become a feature of globalization and it remains as a major source through which developing countries receive foreign exchange. The impact of remittances on households is mixed. Therefore, identifying the reasons that motivate and probe migrant remittance would be important since they are directly related with the migrant as well as household characteristics.

In 1980's, the loss of human capital due to migration was considered to create a negative impact on the developing countries, although the impact of remittances on the country of origin was vast. Sending remittances home can be considered a family adaptation strategy. However, sending money home depends on individual characteristics. A major motive to remit depends on altruism or self-interest (Lucas \& Stark, 1985). However, if a migrant's major intention that affects his decision is to improve the condition of the household or family members left behind, he or she tends to remit as he or she has an obligation to do so. Lucas and Stark (1985) term this as an implicit family agreement in a family framework of decision making, where remittances are endogenous to the migration process. In a macro sense, the intention to remit by migrants depends on the portfolio management decision; a migrants' savings that are not needed for consumption may be remitted.

Individual education levels (Johnson \& Whitelaw, 1974) and the number of children (Lucas \& Stark, 1985) that the migrant have are positively related to a migrants' decision to remit. At the household level, if the migrant is the head of that particular household, then the tendency to remit is higher and they remit more due to the obligation towards family (Oberoi, Prasad, \& Sardana, 1989). Massey and Basem (1992) state that 
migrants who own physical properties or business at their origin tend to remit and invest on more productive activities. In a study based on a data set from Germany, Sweden and Belgium, Lianos (1997) shows that the volume of remittances sent is affected by the level of income of the migrant, the rate of inflation, the exchange rate, the rate of interest and the number of migrants in a family. The author also notices that the level of unemployment affects the remittance sending behavior more often than not. However, in Turkey, neither variation in exchange rate nor changes on real return on investments affect the flow of remittances (Straubbaar, 1986). Hunte (2004) argues and confirms that sending remittances decreases with the increase in household income.

\section{Methodology}

\section{Data}

This study uses data from the Household Income and Expenditure Survey conducted by the Department of Census and Statistics in Sri Lanka during the period of 2009/2010. This survey was conducted over a period of 12 months (July 2009 to June 2010) to capture seasonal variations. The data set comprises 19,958 households and it represents the rural, urban and estate sector areas on a national level. The data is on demographic and socioeconomic variables, also including detailed information about the income and expenditure of each household. As this survey was not designed to gather information on migrant and remittance information, it had collected data on current remittances and transfers from both outside and from within the country. This study employs only the data that belong to 12,857 rural households. The data includes 10,714 non-migrant households and 2,135 migrant households. Among the migrant households, 1,525 households are local (internal) migrant households while 610 households are international migrant households. Out of the migrant households, 986 households receive remittances and 1,157 households do not receive remittances. Among the remittance receiving households 518 households receive internal remittances and 468 households receive international remittances.

\section{Empirical Strategy}

The central objective of this paper is to examine the factors that affect migration and the receipt of remittances. When looking at the nature of the data set, the decision to migrate can be considered under four categories: no 
migration, internal migration, international migration and both internal and international migration. In other words, the rural sub sample can be divided mainly into those three types of households. Therefore, the Multinomial Logit Regression Model was used as the functional model in this study in finding the determinants. The economic theory behind this model is the Expected Utility theory. The model is based on the hypothesis that the unobservable parts of the utility functions are independently and identically distributed with the type 1 extreme value distribution.

Let $U_{i j}$ denotes that the household derives utility by choosing one of the four outcomes and where $\gamma_{j}$ varies and $X_{i j}$ remains constant across alternatives; and $e_{i j}$ is a random error term reflecting intrinsically random choice behavior, measurement or specification error and unobserved attributes of the alternative outcomes. $U_{0}, U_{1}, U_{2}$ and $U_{3}$ denote $\mathrm{i}^{\text {th }}$ household's expected utility from four status of migration viz no migrant, internal migrant, international migrant and households having both types of migration respectively. The observed variable in this case is not the expected utility but the migration choice decision $U_{i j}$.

$$
U_{i j}\left\{\begin{array}{l}
0 \text { if } U_{0}>U_{1}, U_{0}>U_{2} \text { and } U_{0}>U_{3} \\
1 \text { if } U_{1}>U_{0}, U_{1}>U_{2} \text { and } U_{1}>U_{3} \\
2 \text { if } U_{2}>U_{0}, U_{2}>U_{1} \text { and } U_{2}>U_{3} \\
3 \text { if } U_{3}>U_{0}, U_{3}>U_{1} \text { and } U_{3}>U_{2}
\end{array}\right.
$$

Each household's expected utility under each migration status is assumed to be a function of a vector of explanatory variables $X_{i j}$ plus random disturbance $\left(e_{i j}\right)$ that capture unmodelled effects.

$$
U_{i j}=\gamma_{j} X_{i j}+e_{i j}
$$

We model the choice of migration using the Multinomial Logit Model (Babcock, Loewenstein, Issacharoff, \& Camerer, 1995) and it is given by:

$$
P_{i j}=\frac{\exp \left(X_{j} \beta_{j}\right)}{\sum_{j=0}^{j} \exp X_{j}}
$$

For $\mathrm{j}=0 \ldots 3$ 
Let also $\boldsymbol{P}_{\boldsymbol{i} \boldsymbol{j}}(\mathrm{j}=0,1,2,3)$ denote the probability associated with the three choices for total rural sector sample, with $\mathrm{j}=0$ denoting households with no migrants, $j=1$ denoting households with internal migration and $j=2$, denoting households with international migration and $\mathrm{j}=3$ denoting households with both types of migrants. Among the four categories of migration, households with no migration are used as the base category.

The study also focused on analyzing the determinants of sending remittances. The migrant's sub sample was used for this purpose. Thus, $\mathrm{j}=0$ denotes non-remittance receiving households, $j=1$ denotes local remittance receiving households' and $\mathrm{j}=2$ denotes international remittance receiving households in the Multinomial Logit Model. Non-remittance receiving households were used as the base category in this sample. Multinomial Logit Models were used separately for rural sector households and the sub sample of migrant households within the rural sector. 
Table 1: Description of Variables

\begin{tabular}{|c|c|}
\hline Variable & Unit of Measurement \\
\hline \multicolumn{2}{|l|}{ Household Characteristics } \\
\hline Age of household head & Years \\
\hline Education level of household head & Years \\
\hline Gender of household head & dummy where $1=$ Male, $0=$ otherwise \\
\hline Marital status of the household head & dummy where $1=$ Married, $0=$ otherwise \\
\hline Number of members over age 15 & Number \\
\hline Total household size & Number \\
\hline Number of workers over age 15 & Number \\
\hline Number of young dependents & Number \\
\hline Number of old dependents & Number \\
\hline \multicolumn{2}{|l|}{ Human Capital Characteristics } \\
\hline $\begin{array}{l}\text { Number of members over age } 15 \text { with above } \\
\text { A/L education }\end{array}$ & Number \\
\hline $\begin{array}{l}\text { Number of members over age } 15 \text { with } \mathrm{A} / \mathrm{L} \\
\text { education }\end{array}$ & Number \\
\hline $\begin{array}{l}\text { Number of members over age } 15 \text { with } \mathrm{O} / \mathrm{L} \\
\text { education }\end{array}$ & Number \\
\hline $\begin{array}{l}\text { Number of members over age } 15 \text { with grade } \\
6-10 \text { education }\end{array}$ & Number \\
\hline $\begin{array}{l}\text { Number of members over age } 15 \text { with grade } \\
1-5 \text { education }\end{array}$ & Number \\
\hline $\begin{array}{l}\text { Number of members over age } 15 \text { with no } \\
\text { education }\end{array}$ & Number \\
\hline \multicolumn{2}{|l|}{ Network } \\
\hline Sinhala household & dummy where $1=$ Sinhala, $0=$ otherwise \\
\hline Sri Lankan Tamil household & $\begin{array}{l}\text { dummy where } 1=\text { Sri Lankan Tamil, } \\
0=\text { otherwise }\end{array}$ \\
\hline Indian Tamil household & $\begin{array}{l}\text { dummy where } 1=\text { Indian Tamil, } \\
0=\text { otherwise }\end{array}$ \\
\hline \multicolumn{2}{|l|}{ Wealth } \\
\hline Livestock Owner & dummy where $1=$ yes, $0=$ otherwise \\
\hline Agricultural Land Owner & dummy where $1=$ yes, $0=$ otherwise \\
\hline Durable Assets owned & Percentage \\
\hline \multicolumn{2}{|l|}{ Distance } \\
\hline Distance to Divisional Secretariat Office & Minutes (a proxy for distance) \\
\hline Distance to Grama Niladari Office & Minutes(a proxy for distance) \\
\hline
\end{tabular}




\section{Results and Discussion}

Firstly, the summary statistics of the total sample and the migrant sub sample is presented. Next, the results of the Multinomial Logit Models are presented. To achieve the objective of finding the determinants of migration and remittances, two Multinomial Logit Models were estimated separately for total rural sample and migrant sample respectively.

\section{Summary Statistics}

Table 2 summarizes the data related to the rural sector and Table 3 summarizes the data related to the migrant subsample within the rural sector of Sri Lanka. The data herein are described in an abbreviated form. Table 2 presents the results related to $t$-tests that were used to compare the differences between migrant and non-migrant households.

Table 2: Summary Statistics of Selected Variables of Rural Households

\begin{tabular}{|c|c|c|c|c|c|}
\hline Variable & $\begin{array}{l}\text { Mean } \\
\text { NMH }\end{array}$ & $\begin{array}{l}\text { Mean } \\
\text { IMH }\end{array}$ & $\begin{array}{l}\text { Mean } \\
\text { IntMH }\end{array}$ & $\begin{array}{c}\text { t-test } \\
\text { NMH Vs. } \\
\text { IMH }\end{array}$ & $\begin{array}{c}\text { t-test } \\
\text { NMH Vs. } \\
\text { IntMH }\end{array}$ \\
\hline Age of household head & 50.920 & 51.000 & 48.920 & -0.490 & $3.440 * * *$ \\
\hline $\begin{array}{l}\text { Education level of household } \\
\text { head }\end{array}$ & 7.810 & 8.050 & 7.770 & $-2.310 * *$ & 0.450 \\
\hline Total household size & 4.080 & 4.870 & 5.020 & $-17.620 * * *$ & $-12.970 * * *$ \\
\hline Number of members over age 15 & 2.980 & 3.960 & 3.840 & $-25.520 * * *$ & $-13.100 * * *$ \\
\hline Number of workers over age 15 & 1.430 & 1.130 & 0.970 & $11.170 * * *$ & $11.510 * * *$ \\
\hline Number of young dependents & 1.110 & 0.980 & 1.250 & $4.610 * * *$ & $-3.440 * * *$ \\
\hline Number of old dependents & 0.350 & 1.560 & 1.380 & $-63.030 * * *$ & $-28.860 * * *$ \\
\hline $\begin{array}{l}\text { Number of members overage } 15 \\
\text { with above A/L education }\end{array}$ & 0.070 & 0.064 & 0.030 & 0.650 & $3.290 * * *$ \\
\hline $\begin{array}{l}\text { Number of members overage } 15 \\
\text { with } A / L \text { education }\end{array}$ & 0.510 & 0.490 & 0.460 & 0.770 & 1.570 \\
\hline $\begin{array}{l}\text { Number of members overage } 15 \\
\text { with } \mathrm{O} / \mathrm{L} \text { education }\end{array}$ & 0.340 & 0.290 & 0.300 & $2.370 * *$ & 1.240 \\
\hline $\begin{array}{l}\text { Number of members overage } 15 \\
\text { with grade } 6-10 \text { education }\end{array}$ & 1.370 & 1.210 & 1.310 & $5.160 * * *$ & 0.940 \\
\hline $\begin{array}{l}\text { Number of members overage } 15 \\
\text { with grade } 1-5 \text { education }\end{array}$ & 0.490 & 0.450 & 0.450 & $1.990 * *$ & 1.420 \\
\hline $\begin{array}{l}\text { Number of members overage } 15 \\
\text { with no education }\end{array}$ & 0.110 & 0.100 & 0.090 & 0.170 & 0.940 \\
\hline $\begin{array}{l}\text { Distance to Divisional Secretariat } \\
\text { office }\end{array}$ & 35.070 & 37.260 & 34.190 & $-3.320 * * *$ & 1.130 \\
\hline Distance to Grama Niladari office & 12.280 & 12.510 & 11.980 & -0.870 & 0.820 \\
\hline
\end{tabular}

Source: Survey Data.

Note: *Significance at $10 \%$; ** Significance at $5 \%$; *** Significance at $1 \%, \mathrm{NMH}=$ Non Migrant Households; IMH=Internal Migrant Households; IntMH=International Migrant Households. 
The table shows very important contrasts among three types of households. The household heads in families with no migrants are older than those in international migrant families. Household heads in internal migrant families are more educated and their mean education level is eight years. According to existing literature, the family size is a major determinant of migration (Mincer, 1978; Stark, 1991; Mendola, 2008) and our results reveal that internal and international households have more family members. The results also portray that these households have a increased number of working aged members.

However, the number of members who are employed in either the government or private sector is less in migrant families. The number of members over age 15 is higher in non-migrant families in comparison to migrant families. In the case of young and old dependents, the data reveals that there are more old dependents in internal as well as international migrant families, although it is not so with young dependents, i.e. a higher number of young dependents are found in international migrant families in comparison to families with no migrants, this remains the opposite with regard to internal migrant families. It is evident from literature such as Sjaastad (1962), Adams (1989), Larson and Mundlak (1997), Mora and Taylor (2006), and Matsumoto et al. (2006) that human capital characteristics are important determinants of migration decision. Therefore, we used a number of members with different education levels as one indicator of the migration decision. The summary statistics presented in the table suggests that more educated people are found in families without migrants. This is contradictory to what is found in the existing literature. Our expectation is that all types of migrant families have an increased number of educated. However, the case remains different in the rural sector in Sri Lanka.

Table 3 shows a summary of statistics related to the migrant sub-sample within rural households. $t$-test results revealed that the head of the household is older in households that are a part of the no remittances category and the education level of the household head is higher in internal remittance receiving households. However, the mean education level is 8.26 years. It is also evident that families that do not receive remittances have a less number of members in their families in comparison to international 
remittance receiving households. Both internal and international remittance families have just a few number of members who are employed and are over the age fifteen. The table further reveals that remittance receiving households have more young dependents while there are more old dependents in households that do not receive international remittances. With regard to human capital variables, households that do not receive remittances comprise of people who are more educated.

Table 3: Summary Statistics of Selected Variables of Migrant Sub Sample of Rural Households

\begin{tabular}{|c|c|c|c|c|c|}
\hline Variable & $\begin{array}{l}\text { Mean } \\
\text { NRH }\end{array}$ & $\begin{array}{c}\text { Mean } \\
\text { IRH }\end{array}$ & $\begin{array}{c}\text { Mean } \\
\text { IntRH }\end{array}$ & $\begin{array}{c}\text { t-test } \\
\text { NRH Vs. } \\
\text { IRH }\end{array}$ & $\begin{array}{c}\text { t-test } \\
\text { NRH Vs. } \\
\text { IntRH }\end{array}$ \\
\hline Age of household head & 52.270 & 48.460 & 47.820 & $3.660 * * *$ & $4.630 * * *$ \\
\hline Education level of household head & 7.900 & 8.260 & 7.820 & $-2.060 * *$ & 1.030 \\
\hline Total household size & 4.870 & 4.850 & 5.070 & 0.940 & $-2.330 * *$ \\
\hline Number of members over age 15 & 4.050 & 3.730 & 3.810 & $3.320 * * *$ & $1.770 *$ \\
\hline Number of Workers over age 15 & 1.280 & 0.890 & 0.840 & $5.370 * * *$ & $6.570 * * *$ \\
\hline Number of young dependents & 0.880 & 1.220 & 1.320 & $-3.940 * * *$ & $-5.870 * * *$ \\
\hline Number of old dependents & 1.530 & 1.560 & 1.390 & -1.640 & $3.460 * * *$ \\
\hline $\begin{array}{l}\text { Number of members over age } 15 \\
\text { with above } \mathrm{A} / \mathrm{L} \text { education }\end{array}$ & 0.070 & 0.040 & 0.010 & 1.450 & $3.640 * * *$ \\
\hline $\begin{array}{l}\text { Number of members over age } 15 \\
\text { with } A / L \text { education }\end{array}$ & 0.540 & 0.380 & 0.450 & $3.390 * * *$ & 1.060 \\
\hline $\begin{array}{l}\text { Number of members over age } 15 \\
\text { with } \mathrm{O} / \mathrm{L} \text { education }\end{array}$ & 0.310 & 0.220 & 0.320 & $3.060 * * *$ & -1.170 \\
\hline $\begin{array}{l}\text { Number of members over age } 15 \\
\text { with grade } 6-10 \text { education }\end{array}$ & 1.240 & 1.210 & 1.280 & 0.830 & -0.990 \\
\hline $\begin{array}{l}\text { Number of members over age } 15 \\
\text { with grade } 1-5 \text { education }\end{array}$ & 0.470 & 0.420 & 0.430 & 1.150 & 0.730 \\
\hline $\begin{array}{l}\text { Number of members over age } 15 \\
\text { with no education }\end{array}$ & 0.110 & 0.090 & 0.090 & 0.490 & 0.460 \\
\hline $\begin{array}{l}\text { Percentage of durable Assets } \\
\text { owned }\end{array}$ & 24.940 & 24.930 & 25.790 & 0.330 & -1.060 \\
\hline $\begin{array}{l}\text { Distance to Divisional Secretariat } \\
\text { office }\end{array}$ & 35.910 & 39.840 & 33.550 & $-3.420 * * *$ & $2.560 * *$ \\
\hline Distance to Grama Niladari office & 12.430 & 13.260 & 11.180 & $-2.290 * *$ & $2.830 * * *$ \\
\hline
\end{tabular}

Source: Survey Data.

Note: $*$ Significance at $10 \%$; $* *$ Significance at $5 \%$; *** Significance at $1 \%, \mathrm{NRH}=$ Non Remittance Receiving Households; IRH=Internal Remittance Receiving Households; IntRH=International Remittance Receiving Households.

\section{Estimated Results of Econometric Model}

In finding the determinants of migration and remittances, we estimated two Multinomial Logit Models for both the total sample and the migrant subsample. The study examined the Multinomial Model for the total sample 
considering four types of households viz no migrant, internal migrant, international migrant and households having both types of migration. Three types of households were examined in order to estimate the determinants of remittances, viz households that do not receive remittances, receive internal remittances and receive international remittances respectively.

Table 4 presents the results of the Multinomial Logit Regression which was run to identify the determinants of migration in rural households of Sri Lanka. Surprisingly, the results reveal that most of the variables affect migration decisions negatively. The results portray that only age of the household head, household size and the number of old dependents affect the migration decision positively, when household characteristics are concerned. The age of the household head provides a proxy for experience in working in any sector. Therefore, with experience, the household heads have understood the importance of releasing a member of their households for migration. The literature by Adams (2006) emphasizes that households with older household heads produce more migrants since they have more members that have the ability to migrate. It is also a fact that the age of the household head is a proxy for experience of the household head in rural work. Therefore, we could expect an either negative or positive association of migration with the age of the household head. Akhter and Bauer (2014) also argue that the sign of the age of the household head can be positive or negative. The studies of Kaimba, Njehia and Guliye, (2011), and Lewin et al. (2012) find a negative sign of age for migration decision. Hence, it could be expected that with increase in the age of the household heads, the family may become a stable one and therefore paving way for a less number of migrants in the family. The number of dependents defined as household members who are not currently employed (Zhu \& Luo, 2010), have a strong linkage with migration decisions since they stay at home protecting their properties (Zhao, 1999). Therefore, it can also be assumed that the tendency to migrate may reduce when the households have more dependents, since they should be taken care of. However, our results reveal that the tendency to migrate internally or internationally increases with higher number of old dependents. This variable can have both positive and negative signs on the migration decision. Based on the literature, we can argue that the adult members might be willing to migrate to the city in order to earn an extra income to satisfy the additional expenditure of the young members. At the 
same time, the possibility to stay with their families and look after the young members of the household becomes a negative influence on migration.

Table 4: Multinomial Logistic Regression Results for Total Sample

\begin{tabular}{|c|c|c|c|}
\hline Variable & $\begin{array}{l}\text { Internal } \\
\text { Migration }\end{array}$ & $\begin{array}{l}\text { International } \\
\text { Migration }\end{array}$ & $\begin{array}{c}\text { Internal and } \\
\text { International } \\
\text { Migration }\end{array}$ \\
\hline \multicolumn{4}{|l|}{ Household Characteristics } \\
\hline Age of household head & $0.272 * * *$ & $0.310 * * *$ & $0.342 * * *$ \\
\hline Age square & $-0.004 * * *$ & $-0.004 * * *$ & $-0.005 * * *$ \\
\hline Education level of household head & $-0.136 * * *$ & $-0.136 * * *$ & $-0.147 * * *$ \\
\hline Gender of household head & $-1.952 * * *$ & $-1.535 * * *$ & $-2.009 * * *$ \\
\hline Marital status of household head & $-0.366 * * *$ & $-0.385 * * *$ & -0.414 \\
\hline Total household size & $4.413 * * *$ & $4.085^{* * *}$ & $5.237 * * *$ \\
\hline Number of members over age 15 & $-2.655 * * *$ & $-2.446 * * *$ & $-3.439 * * *$ \\
\hline Number of workers over age 15 & $-0.405 * * *$ & $-0.586 * * *$ & -0.124 \\
\hline Number of young dependents & $-4.693 * * *$ & $-4.228 * * *$ & $-5.724 * * *$ \\
\hline Number of old dependents & $3.760 * * *$ & $3.519 * * *$ & $5.121 * * *$ \\
\hline \multicolumn{4}{|l|}{ Human Capital Characteristics } \\
\hline $\begin{array}{l}\text { Number of members overage } 15 \text { with } \\
\text { above } A / L \text { education }\end{array}$ & $-1.637 * * *$ & $-1.887 * * *$ & $-2.314 * * *$ \\
\hline $\begin{array}{l}\text { Number of members overage } 15 \text { with } \\
\text { A/L education }\end{array}$ & $-1.664 * * *$ & $-1.437 * * *$ & $-2.302 * * *$ \\
\hline $\begin{array}{l}\text { Number of members overage } 15 \text { with } \\
\text { grade 6-10 education }\end{array}$ & $-1.436 * * *$ & $-1.295 * * *$ & $-1.823 * * *$ \\
\hline $\begin{array}{l}\text { Number of members over age } 15 \text { with } \\
\text { grade } 1-5 \text { education }\end{array}$ & $-1.856 * * *$ & $-1.931 * * *$ & $-2.302 * * *$ \\
\hline $\begin{array}{l}\text { Number of members overage } 15 \text { with } \\
\text { no education }\end{array}$ & $-1.682 * * *$ & $-1.637 * * *$ & $-2.373 * * *$ \\
\hline \multicolumn{4}{|l|}{ Network } \\
\hline Sinhala household & $0.609 * * *$ & $-0.777 * * *$ & -0.528 \\
\hline Sri Lankan Tamil household & -0.198 & -0.100 & -0.759 \\
\hline Indian Tamil household & 0.232 & -1.092 & -0.855 \\
\hline \multicolumn{4}{|l|}{ Wealth } \\
\hline Agricultural land owner & $0.241 * * *$ & -0.122 & $0.654 * * *$ \\
\hline Livestock owner & 0.164 & 0.061 & -0.217 \\
\hline Percentage of durable assets owned & $-0.008 * * *$ & -0.004 & 0.004 \\
\hline \multicolumn{4}{|l|}{ Distance } \\
\hline $\begin{array}{l}\text { Distance to Divisional Secretariat } \\
\text { office }\end{array}$ & $0.004 *$ & 0.001 & 0.004 \\
\hline Distance to Grama Niladari office & $0.003 * * *$ & 0.005 & -0.007 \\
\hline Constant & $-7.257 * * *$ & $-7.792 * * *$ & $-12.082 * * *$ \\
\hline
\end{tabular}

Source: Survey Data.

Note: *Significance at $10 \% ; * *$ Significance at $5 \% ; * * *$ Significance at $1 \%$. 
The household size is expected to be positively associated according to the migration theories. According to these theories, the household members tend to migrate with more numbers of members in the households. It is evident that the household size is a major determinant in the migration decision; and the movement of people increase with the increasing family sizes as more labor is available in the households (Dharmadasa \& de Zoysa, 2012).

Migration literature propagate that education levels of migrants and other household members positively influence the migration decision. This is highlighted by Sjaastad (1962), Adams (1989), Larson and Mundlak (1997), Mora and Taylor (2006), and Matsumoto et al. (2006). Almost all the authors stress that propensity to migrate increases with higher education levels of migrants while the educational levels of household heads (Lewin et al., 2012) significantly influence the migration decision. However, this study considered the household level human capital characteristics and the results revealed that almost all human characteristics and the education level of the household head affects migration negatively. This may be due to the fact that higher education levels of the household head may reflect on better household resources and income opportunities and so they may not need to depend on the migration and remittances (McDonald \& Valenzuela, 2012). Kaimba et al. (2011) and McDonald and Valenzuela (2012) also highlight that education attainment of the household head does not correlate with the probability of having a migrant in the households in Kenya and Philippines respectively. It is also a fact that most internal and international migrants from Sri Lanka belong to the unskilled migrant category. This implies that the education level has not been a matter concerning migration. These findings are further stressed in the summary statistics, which shows a very few household members with secondary and higher education in migrant households. Apart from this, networks play an important role in migration decision as it reduces the cost of migration. Therefore, the study utilized nationality as a proxy for network. As a result, being a Sinhala household has a potential advantage in migrating within the country as most of the people in the country are Sinhala. However, it has a negative effect on international migration. If the rural households have agricultural lands, their tendency to migrate internally is higher and this is the foremost problem in the rural sector of Sri Lanka. It is a fact that most rural households are 
farmers in Sri Lanka and they need more labor for their farming activities. However, most of the members in the farming community, especially the younger generation are not interested in farming. This tendency could be seen in the category which consists of both types of migrants. On the other hand, the more the rural people have durable assets; migration will be less internally. The durable assets that they own display their wealth and it can be assumed that wealthy people do not tend to migrate internally. As the distance is associated with the cost of migration, it is assumed that rural people may not migrate for a long distance to get their work done from Divisional Secretariat and Grama Niladhari. However, the results of this study suggest that the distance has a positive effect on migration. The major reason would be that the Divisional Secretariat is located in a city in most cases, and therefore as they also come across opportunities that are available in the cities, the decision to migrate will not be hindered.

Table 5 presents the results of the Multinomial Logit Model that was estimated to find the determinants of sending remittances. In most cases the head of the household is the father or the mother of the family. They have a significance influence over the migration decision and the remittances that are to be sent by those who have migrated. The age of the head of the household is therefore, expected to be related to the receipt of remittance and the amount received. More evidence in favor of the altruistic motive for remitting is consistent with households with older heads receiving more remittances.

Keeping with this fact, the results of Table 5 suggest that the age of the household head is a positive and significant determinant in sending internal remittances. The positive and highly significant sign for the age of the household head could also indicate a bequest motive. The older the household head is, the closer he is to death and the sooner a potential inheritance. A migrant, thus, remits more to be on favorable terms with the household head. This could also be a sign of altruism because the household head is elderly and needs more support (Hagen-Zanker \& Siegel, 2008). 
Table 5: Multinomial Logistic Regression for Migrant Sample

\begin{tabular}{|c|c|c|}
\hline Variable & $\begin{array}{l}\text { Receive Internal } \\
\text { remittance }\end{array}$ & $\begin{array}{c}\text { Receive International } \\
\text { remittance }\end{array}$ \\
\hline \multicolumn{3}{|l|}{ Characteristics of Household } \\
\hline Age of household head & $0.049 *$ & 0.039 \\
\hline Age square & $-0.001 *$ & -0.000 \\
\hline Education level of household head & 0.034 & 0.023 \\
\hline Gender of household head & $-0.690 * * *$ & -0.130 \\
\hline Marital status of household head & $-0.267 * *$ & $-0.240 *$ \\
\hline Total household size & $-0.482 * * *$ & 0.334 \\
\hline Number of members over age 15 & $0.464 *$ & -0.156 \\
\hline Number of workers over age 15 & $-0.459 * * *$ & $-0.535 * * *$ \\
\hline Number of young dependents & $0.656 * * *$ & -0.162 \\
\hline Number of old dependents & 0.054 & -0.026 \\
\hline \multicolumn{3}{|l|}{ Human Capital Characteristics } \\
\hline $\begin{array}{l}\text { Number of members overage } 15 \text { with } \\
\text { above A/L education }\end{array}$ & -0.326 & $-1.510 * * *$ \\
\hline $\begin{array}{l}\text { Number of members overage } 15 \text { with } \\
\text { A/L education }\end{array}$ & 0.165 & 0.032 \\
\hline $\begin{array}{l}\text { Number of members overage } 15 \text { with } \\
\text { grade } 6-10 \text { education }\end{array}$ & $0.273 *$ & -0.075 \\
\hline $\begin{array}{l}\text { Number of members overage } 15 \text { with } \\
\text { grade } 1-5 \text { education }\end{array}$ & 0.273 & $-0.338^{*}$ \\
\hline $\begin{array}{l}\text { Number of members overage } 15 \text { with no } \\
\text { education }\end{array}$ & -0.194 & $-1.049 * * *$ \\
\hline \multicolumn{3}{|l|}{ Network } \\
\hline Sinhala household & 0.668 & $0.281 * * *$ \\
\hline Sri Lankan Tamil household & $0.608 * * *$ & -1.344 \\
\hline Indian Tamil household & -0.573 & $-1.344 * * *$ \\
\hline \multicolumn{3}{|l|}{ Wealth } \\
\hline Agricultural land owner & -0.051 & -0.193 \\
\hline Livestock owner & 0.134 & -0.043 \\
\hline Percentage of durable assets owned & 0.001 & 0.001 \\
\hline \multicolumn{3}{|l|}{ Distance } \\
\hline Distance to Divisional Secretariat office & 0.006 & -0.001 \\
\hline Distance to Grama Niladari office & $0.002 * * *$ & -0.007 \\
\hline Constant & $-2.173 * * *$ & -0.498 \\
\hline
\end{tabular}

Source: Survey Data.

Note: *Significance at $10 \% ; * *$ Significance at $5 \%$;** Significance at $1 \%$.

It is also evident that migrants send remittances when the household has more young dependents and more family members under the age of fifteen. A more number of young dependents imply a high number of children in the school going ages. Therefore, the migrants who have a higher number of children tend to remit more. Most authors find a positive effect of the household size in estimations of the probability and level of remittances (Osili, 2007). However, the findings of this study reveal that most 
importantly, the household size is a negative determinant of the receipt of internal remittances (Hagen-Zanker \& Siegel, 2008). This is a contradictory finding because the study's expectation is that migrants will send remittances when the household has more members. According to finding of the World Bank (2007), most of the internal migrants perform ad hoc jobs in the towns and cities and thus their daily earnings is sufficient for their living only. Therefore, they do not tend to remit although their family size is big. The sign for the number of workers in households is negative, thus indicating the propensity to migrate and receive remittances from both the types of migrants to reduce despite the increasing numbers of workers in the household. When the household has a higher number of people employed, the household may not require the assistance from those who have migrated since they each earn sufficiently from their own employment. Therefore, migrants tend not to remit when the household has more employed people.

In the case of the receipt of remittances, human capital characteristics play a negative role in international migration. The effect of education levels on the probability of migration and/or remittances may be positive or negative (Hagen-Zanker \& Siegel, 2008). However, having more members with 6-10 years education level has a positive significant effect on the receipt of internal remittances while the sign for the human capital variable for a number of members aged over fifteen with Advanced Level qualification is negative. Some research suggests that migration is negatively associated with education (Mora \& Taylor, 2006). This is a clear indication that Sri Lanka does not experience a grave threat of brain drain. The propensity receive remittances from international remittances is high if the household is Sinhala while Sri Lankan Tamil households also receive more remittances from their internal migrants. The majority of rural households in Sri Lanka are Sinhala and therefore many migrants are Sinhalese. Consequently, they tend to remit to their households left behind. The next majority within the rural sector are Sri Lankan Tamils and they also receive remittances from their internal migrants.

\section{Conclusion}

This paper studied the determinants of migration and the receipt of remittances by analyzing household data collected by the Department of 
Census and Statistics with the use of Multinomial Logit Regression Models. Migration and receiving remittances by the rural household is very important when developing the rural sector. In a way, the remittances from migrants can also be used as an input in the agricultural production of rural households. On the other hand, remittances contribute to enhance the education levels of households. Therefore, the decision to migrate and to receive remittances from migrants, depend on human capital characteristics. However, this study concludes that human capital characteristics are not major positive determinants of the rural sector. Increasing the household size means an extra burden to the households as more people are to be fed. Therefore, the income and the earning capacity of the household should somehow increase or else they have to diversify their income. Therefore, the household members choose to migrate internally or internationally to diminish this constraint. The results of the study showcases this notion as it portrays how the propensity to migrate increases with increase of household members.

However, this is not the case with the remittance receipt. While the household size is a negative determinant in receiving remittances from internal migrants; migrants tend to remit more when they have young dependents i.e. school age children. This is because they have a responsibility towards these school-aged children. Most people in the rural sector are engaged in agricultural activities. However, the propensity to migrate is very high when the younger generation moves away from engaging in traditional agricultural activities. Finally, this study concludes that human capital characteristics contribute to keep the household members within the rural sector. Therefore, if proper policies are implemented, the retaining human capital can be employed for the rural development process.

\section{Acknowledgement}

This paper was presented at the 14th International Conference on Business Management (ICBM) held at Taj Samudra Hotel on $8^{\text {th }}$ December, 2017. We would like to acknowledge the reviewers and other academics for their valuable comments and guidance in improving this research paper.

\section{References}

Adams, R. H. (1989). Worker Remittances and inequality in rural Egypt. Economic Development and Cultural Change, 38(1), 45-71. 
Adams, R. H. (2006). Remittances, Poverty, and Investment in Guatemala. In Ozden, C., \& Schiff, M., (Eds), International Migration, Remittances, and the Brain Drain (pp.53-80). Wahington DC: World Bank Publications.

Akhter, S.,\& Bauer, S. (2014). Household level determinants of rural-urban migration in Bangladesh. International Journal of Social, Management, Economics and Business Engineering, 8(1), 24-27.

Babcock, L., Loewenstein, G., Issacharoff, S., \& Camerer, C. (1995). Biased judgments of fairness in bargaining. The American Economic Review, 85(5), 1337-1343.

Cai, F., \& Wang, D. (2003). Migration as marketization: What can we learn from China's 2000 census data? The China Review, 3(2), 73-93.

Central Bank of Sri Lanka (2016). Economic and social statistics of Sri Lanka 2016. Colombo: Author.

Department of Census and Statistics(2015). Final report on the census of population and housing 2012. Colombo: Author.

Department of Census and Statistics (2011). Household income and expenditure survey - 2009/10. Colombo: Author.

Deshingkar, P. (2006). Internal migration, poverty and development in Asia: Including the excluded. IDS Bulletin, 37(3), 88-100.

Dharmadasa, R. A. P. I. S., \& De Zoysa, M. (2012). The determinants of labor outmigration in tea plantation sector in Badulla district. Proceedings of International Conference on Business Management on Capacity Development in a Post-war Context (pp.1-8). Jaffna: Jaffna University, Sri Lanka.

Dharmadasa, R. A. P. I. S. (2016). Impact of labor migration and remittances on poverty, inequality and expenditure pattern of the estate sector, Sri Lanka (Unpublished doctoral dissertation). Postgraduate Institute of Agriculture, University of Peradeniya, Sri Lanka.

Eelens, F., \& Schampers, A. J. (1990). Sri Lankan housemaids in the Middle East. Genus, 46(3-4), 97-107.

Greenwood, M. J. (1970). Lagged response in the decision to migrate. Journal of Regional Science, 10(3), 375-84.

Hagen-Zanker, J., \& Siegle, M., (2008). A critical discussion of the motivations to remit in Albania and Moldova (Working Paper No. 30/88). Warsaw: Warsaw University, Poland. 
Harris, J. R., \& Todaro, M. P. (1970). Migration, unemployment and development: A theoretical analysis. American Economic Review, 60, $126-142$.

Housen, T., Hopkins, S., \& Earnest, J. (2013). A systematic review on the impact of internal remittances on poverty and consumption in developing countries: Implications for policy. Population Space and Place, 19(5), 610-632.

Hunte C. K. (2004). Workers' remittances, remittance decay and financial deepening in developing countries. American Economist. 48(2), 82-94.

International Organization for Migration [IOM] (2005). Migration and remittances in Moldova. Moldova: Author.

Jayawardhana, T., \& Jaythilaka, R. (2009). International migration outlookSri Lanka, 2008.Colombo: International Organization for Migration.

Johnson, G. E., \& Whitelaw W. E. (1974). Urban - rural income transfer in Kenya: An estimated - remittances function. Economic Development and Cultural Change, 22(3), 473-79.

Kaimba, G. K., Njehia, B. K., \& Guliye, A. Y. (2011). Effects of cattle rustling and household characteristics on migration decisions and herd size amongst pastoralists in Baringo district, Kenya. Pastoralism: Research, Policy and Practice, 1(1), 1-18.

Larson, D., \& Mundlak, Y. (1997). On the inter-sectoral migration of agricultural labor. Economic Development and Cultural Change, 45(2), $259-319$.

Lee, E. S. (1966). A Theory of Migration. Demography, 3(1), 47-57.

Lewin, P. A., Fisher, F., \& Weber, B. (2012). Do rainfall conditions push or pull rural migrants: Evidence from Malawi. Agricultural Economics, 43(2), 191-204.

Lianos, T. (1997). Factors determining migrant remittances: The case of Greece. International Migration Review, 31(1), 72-87.

Lucas, R., \& Stark, O. (1985). Motivations to remit: Evidence from Botswana. Journal of Political Economy, 93(5), 901-918.

Massey, D. S., \& Basem, L. C. (1992). Determinants of savings, remittances, and spending patterns among US migrants in four Mexican communities. Sociological Inquiry, 62(2), 431-466.

Matsumoto, T., Kijima, Y., \& Yamano, T. (2006). The role of local nonfarm activities and migration in reducing poverty: Evidence from Ethiopia, Kenya, and Uganda. Agricultural Economics, 35(3), 449-458. 
McDonald J. T., \& Valenzuela, R. (2012). Why Filipino migrants remit? Evidence from a home-host country matched sample (Working Paper No. 9/12). Clayton: Monash University.

Mendola, M. (2008). Migration and technological change in rural households: Complements or substitutes. Journal of Development Economics, 85(1-2), 150-175.

Mincer, J. (1978). Family migration decisions. Journal of Political Economy, 86(5), 749-773.

Mora, J., \& Taylor, J. E. (2006). Determinants of migration, destination, and sector choice: Disentangling individual, household, and community effects.In Ozden, C., \&Schiff, M. (Eds), International migration, remittances and the brain drain (pp.21-52). Washington DC: The World Bank Publications.

Nonthakot, P., \& Villano, R. (2008). Migration and farm efficiency: evidence from northern Thailand. Paper presented at the AARES Fifty Second Annual Conference, Canberra, Australia. Abstract retrieved from https://ideas.repec.org/p/ags/aare08/5981.html

Oberoi, A. S., Prasad, P. H., \& Sardana, M. G. (1989). Determinants and Consequences of Internal Migration in India. New Delhi: Oxford University Press.

Osili, U. (2007). Remittances and savings from international migration: Theory and evidence using a matched sample. Journal of Development Economics, 83(2), 446-456.

Perera, S. (2005). Patterns, determinants and consequences of internal migration in Sri Lanka 1981-2001. IWE Journal, 5, 76-101.

Root, B. D., \& De Jong, G. F. (1991). Family migration in a developing country. Population Studies, 45(1), 221-233.

Ranathunga, S. P. B. (2011). The determinants of household poverty in Sri Lanka: 2006/2007. Paper presented at the Fortieth Annual Student Research Conference, Waikato. New Zealand. Retrieved from https://mpra.ub.uni-muenchen.de/34174/1/MPRA_paper_34174.pdf

Shaw, J. (2008). Migrants remittances and low income households in Sri Lanka: Development policy issues (Working Paper No.09). Clayton: Monash Asia Institute.

Shields, M. P., \& Shields G. M. (1993). A theoretical and empirical analysis of family migration and household production: US 1980-1985. Southern Economic Journal, 59(4), 768-782. 
Sjaastad, L. A. (1962). The costs and returns of human migration. Journal of Political Economy, 70(5), 80-93.

Soubbotina, T. P. (2004). Beyond economic growth: An introduction to sustainable development (2nd ed.). Washington, DC: Word Bank Publications.

Sri Lanka Bureau of Foreign Employment (2016). Annual statistical report of foreign employment 2015. Colombo: Author.

Stark, O. (1991). The migration of labour. Oxford: Blackwell.

Straubhaar, T. (1986). The determinants of workers' remittances: The case of Turkey. Weltwirtschaftliches Archiv, 122(4), 728-40.

Taylor, J. E., Rozelle, S., \& De Brauw, A. (2003). Migration and incomes in source communities: New economics of migration perspective from China. Economic Development and Cultural Change, 52(1), 75-101.

Todaro, M. P. (1969). A model of labor migration and urban employment in less developed countries. American Economic Review, 59(1), 138-148.

Ukwatta, S. (2010). Economic and social impacts of the migration of Sri Lankan transnational domestic workers on families and children left behind. Adelaide: The University of Adelaide.

Ullah, A. K. M. A. (2004). Bright city lights and slums of Dhaka city: Determinants of rural-urban migration in Bangladesh. Migration Letters, 1(1), 26-41.

World Bank (2007). Sri Lanka poverty assessment: Engendering growth with Equity: Opportunities and challenges. Washington DC: World Bank Publications.

Zhao, Y. (1999). Labor migration and earnings differences: The case of rural China. Economic Development and Cultural Change, 47(4), 767782.

Zhu, N., \& Luo, X. (2006). Non-farm activity and rural income inequality: A case study of two provinces in China. Washington DC: World Bank Publications.

Zhu, N., \& Luo, X. (2010). The impact of migration on rural poverty and inequality: A case study in China. Agricultural Economics, 41(2), 191204. 